\title{
エネルギーと農業・土地利用を考慮した インドネシアにおける低炭素社会シナリオの構築
}

\author{
大沢遼平 ${ }^{1} \cdot$ 五味 馨 $^{2^{*}} \cdot$ 松岡 譲 $^{3}$ \\ 1非会員 丸紅株式会社海外電力プロジェ外第三部電気事業第一チーム (广100-8088 東京都千代田区大手町 1-42) \\ 2正会員 国立環境研究所社会環境システム研究センター(テ305-8506つくば市小野川16-2) \\ 3正会員 京都大学大学院工学研究科 教授 ( 6 T66-8530 京都市西京区京都大学桂) \\ *E-mail: gomi.kei@nies.go.jp
}

\begin{abstract}
今後, 人口増加と経済発展が見込まれる東南アジアの新興国のうち, 特にインドネアアおいてはその人口規模の大きさと森林 面積の広さ, バイオ燃料の生産ポテンシャルを含む農業生産の高さなどから将来のGHG排出量増加とその抑制とが世界的な温暖 化緩和において重要になると考えられている.このような人口・経済ともに成長中で今後の食料とエネルギ一需要の増加が見込ま れ,かつ, 農林業・土地利用部門からのGHG排出量の割合が比較的高、地域で低炭素社会を構築するため, 本研究では社会経 済発展の想定を取り込み, エネルギー・農業・土地利用の各部門を統合的に考慮した低炭素社会シナリオの構築手法を開発した. これを2020年及び2050年のインドネシアに適用し，低炭素対策を導入しないBaU及び低炭素対策の違いにより三通りの対策(CM)シ ナリオを構築し, 総合的な低炭素社会シナリオの中で、燃料作物栽培のための土地利用転換による排出も含むバイオ燃料の利用 による正味の効果を考慮する例走示した。
\end{abstract}

Key Words: low-carbon society, climate change, bio fuel, Indonesia, land-use change

\section{1. 背景と目的}

21 世紀に入り, 先進工業国(以下, 先進国)の経済成長が 緩やかになるのとは対照的に, 東南アジア諸国の急速な経 済成長が目立つようになってきた. GDP 成長率でみると, 2014 年度は先進国が 2.0\%と予想されているのに対し， ASEAN-5 と呼ばれる国々(GDP 規模において東南アジアの 上位五か国であるインドシア, タイ, マレーシア, フィリピン, ベトナム)では 5.1\%から 7.3\%となっている1). その結果, それら の地域におけるエネルギー消費量が増え, 人為起源の温室 効果ガス(Greenhouse Gas; GHG)の排出量が増加すると考えら れる. そのような状況の中, 世界各国では自主的な GHG 排 出削減目標の策定が進んでおり, 東南アジアの経済成長を 考える上で重要視されているインドネシアもその国の一つで ある. World Resource Instituteによると 2011 年においてイイドネ シアの GHG 排出量は世界の国の中で第 5 位である2). 今後 も人口が増えると予想されており, GDP も成長中であるインド ネシアでは, 何も対策を施さなかった場合, GHG 排出量の増 加が予測される. インドネシアでの GHG排出量削減に関して, $\mathrm{DNPP}^{3}$ は土泥炭部門, LULUCF (森林と土地利用, 土地利用転 換)部門, 電力部門, 交通部門, 石油とガス部門, セメント部 門, 農業部門, 建築物部門からの排出量をそれぞれ求めて いる. それぞれの分野で限界削減費用曲線を使い, 2030 年
のインドネシアの GHG 排出量の削減ポテンシャルと削減に かかるコストを計算している. しかし,このような部門別の排出 削減シナリオでは十分に考慮出来ない低炭素対策としてバ イオ燃料がある.インドネシアではバイオ燃料の普及を積極 的に進めている.一般的にバイオ燃料の利用促進は低炭素 対策とみなされているが，土地利用転換からの排出量を考慮 しないバイオ燃料の普及は更に GHG 排出量を増加させると の懸念がある. UNEP汭バイオ燃料の化石燃料と比較した 正味の GHG収支の推計值には幅があり, 特にパーム由来バ イ才燃料は $80 \%$ 削減から 2,070\%増加まで幅広い推計值が報 告されている.このような人口・経済ともに成長中で今後の食 料とエネルギ一需要の増加が見込まれ，かつ, AFOLU 部門 からの GHG 排出量の割合が比較的高、地域で低炭素社会 を構築するには, 社会経済発展の想定を取り込み, エネルギ 一・AFOLU 両部門を統合し, 両部門間の関係も考慮した低 炭素社会シナリオの構築が必要であると考えられる. そこで 本研究ではこのようなシナ少オの構築手法を開発し, 2020 年 及び 2050 年のインドネンアにこれを適用してシナリオの例を 示すことを目的とする。

\section{2. 研究の手法}

\section{(1) 研究の全体像}

図-1に低炭素社会シナ少才構築手法の全体像を示寸. 


\section{(2) モデル}

本研究ではインドネシアの将来像を推計するために2つ のモデル, ExSS, AFOLUAを組み合わせて低炭素社会シナ リオの構築を行う. 以下にそれらの概要を示す.

\section{a) ExSS}

ExSS は, 五味らのが低炭素社会ビジョン構築のために開 発したツールである. ExSS はある地域, または全地域の目標 年の社会像を社会経済指標, 二酸化炭素排出量, エネルギ 一需要量, エネルギ一利用技術などから整合的, 定量的に 表現, 評価するツールとして開発された. 社会経済指標とは 社会の姿を定量的に表す指標であり, 具体的に人口, GDP, 交通需要量などが含まれる. ExSS はこれらの指標を推計し， その下で, 目標年の排出量を達成するための低炭素対策を 同定することができる.

ExSS は勘定表型の静学モデルである.このツール内は連 立方程式体系で記述されており, 方程式の数は内生変数の 数と同じとなっているため, 与えられた外生変数のもとで解は 一意的に決まる. 低炭素対策は各部門・サービス別のエネル ギー効率, 燃料シェアなどの形で与えられる. 計算プログラム の記述には GAMS (General Algebraic Modeling System)老利用 して非線形計画法しして定式化し, 求解ソフトウェア(Solver)に は非線形計画法の求解に優れた CONOPTを利用している.

b) AFOLUA

AFOLUA は三隅 わによって開発されたツールである.
AFOLUA モデルは低炭素社会としての将来ビジョンを構築 するために, 農畜産業・森林・土地利用の各部門の将来の活 動状況を描写し, GHG 排出量および排出削減量を推計する ために開発された. AFOLUA の計算体系の概略を図-2 に示 す.

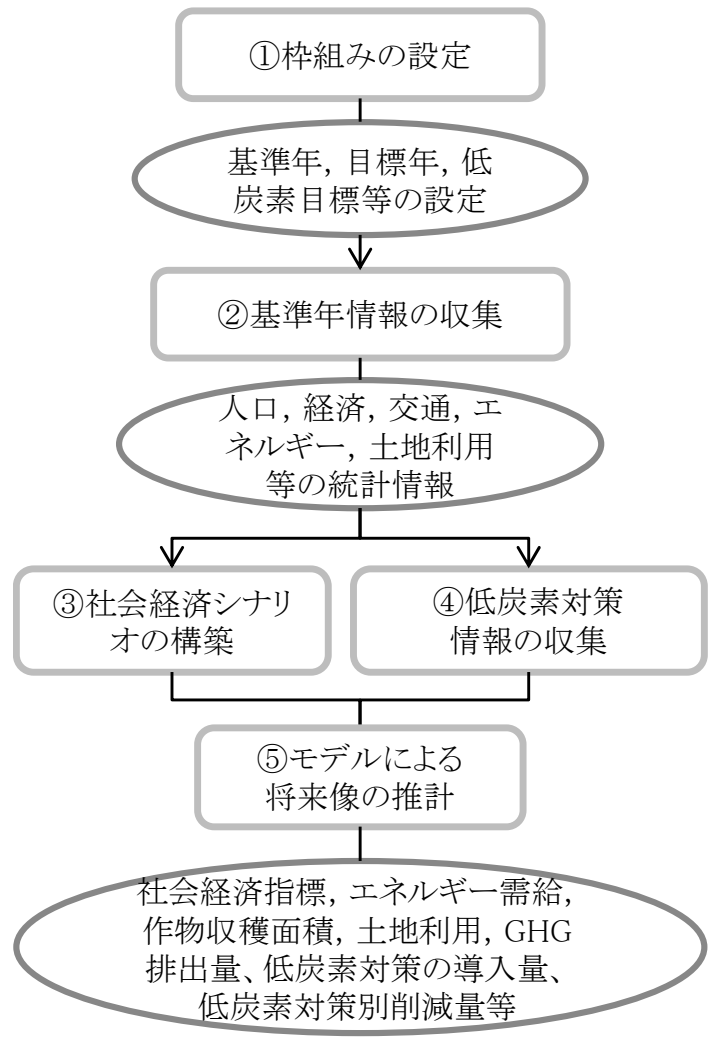

図-1 研究の全体像

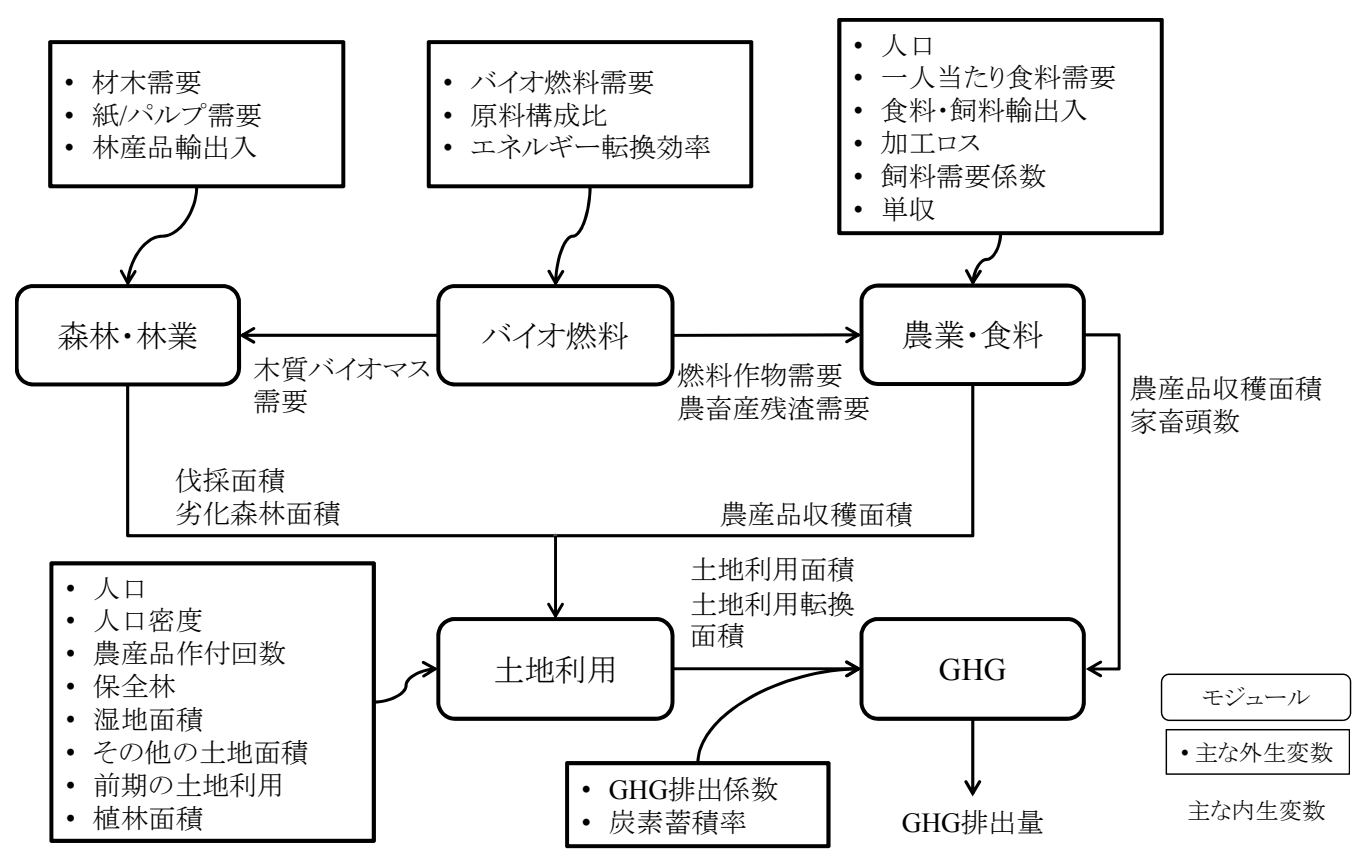

図-2 AFOLUAの計算体系

人口の増加や食糧需要構造の変化, 食糧の輸出入など に伴い農畜産業による食糧や飼料の生産は変化し, その生
産のために必要な土地利用にも, 例えば農地や草地拡大の ための森林伐採しいった形で影響を与える. 単収の増加によ 
り単位作物生産あたりの土地需要が減少することもある. また 特に GHG 排出についていえば, エネルギ一部門の GHG 排 出量削減策とみなされるバイオ燃料の生産は農地を需要し, 森林伐採によるGHG排出増加の原因となりもする. AFOLUA モデルは主ししてこれら部門の整合的な活動量(食糧生産, 作物収穫面積, 家畜頭数, 土地面積, 土地利用変化)の推 計を主な目的としている. AFOLUA モデルは人口と食料, そ してバイオ燃料需要を起点としてこれらの関係を記述し, AFOLU部門の活動量の変化による将来の GHG排出量への 影響を示すことが出来る.

食料・農業, バイオ然料, 森林・林業, 土地利用, GHGの 4 つのモジュールによって構成されている. 食料・農業モジュ 一ルでは人口と一人あたりの食料需要から対象地域全体の 食料消費量を求め, これに輸出入を考慮して地域内での食 料生産量を得る. 農産品の生産量と単収から収穫面積を, 畜産品の生産量力ら家畜頭数をそれぞれ求める. 飼料生産 もここで考慮される. バイオ燃料モジュールでは外生的に与 えられるバイオ然料需要を満たす原料の必要量を推計する. 原料のうち農産品は農産品の需要量しして食料・農業モジュ 一ルに送られる. 農業残椬や林産物からのバイオ燃料の生 産も記述し, 農業残椬の需要量は食料・農業モジュールへ, 林産物の需要量は森林・林業モジュールへ, それぞれ送ら れる. 森林・林業モジュールは外生的に与えられる林産品の 国内需要と輸出入から国内生産量を求女, 材木切り出しの夕 イプ別に森林の劣化及び伐採面積を求める. 土地利用モジ ユールでは次のようにして各土地利用区分の土地利用面積 を求める.

- 農産品の収穫面積と作付け回数から農地面積

- 家畜頭数と放牧される家畜 1 頭あたりの草地面積需要 加草地面積

- 人口と人口密度の想定から宅地面積

・森林の伐採面積及び保全林の想定から森林面積 その他の土地利用面積は外生的に与えられる. 次いで各 土地利用の前期の面積亡土地利用転換係数の想定加ら口 スエントロピー法を用いて土地利用転換マトリクスを推計する. すなわち, $x_{i j}$ を前期から当期への土地利用転換行列として，

$$
\begin{gathered}
\sum_{i, j} p_{i, j} \log \frac{p_{i, j}}{q_{i, j}} \rightarrow \mathrm{MIN} \\
p_{i, j}=\frac{x_{i, j}}{\sum_{j} x_{i, j}} \\
\sum_{j} x_{i, j}=u_{i} \\
\sum_{i} x_{i, j}=u_{j}
\end{gathered}
$$

ここに,

$p_{i j}$ : 前期力 $\left.\left(p_{i j}\right)=1\right)$ $q_{i j}$ : 参照土地利用転換係数 $\left(0 \leqq q \leqq 1, \Sigma_{j}\left(q_{i j}\right)=1\right)$

$i$ : 前期の土地利用種

$j$ : 当期の土地利用種

$u_{i}$ 前期の土地利用

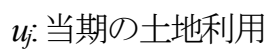

このように土地利用転換を定式化することにより, 前期から当 期への土地利用 $i$ から土地利用 $j$ への転換割合を与えられ た参照土地利用転換係数に近づけるよう定式化されている. このとき $q_{i j}$ を過去の土地利用転換行列から推計することで, 過去に起きた土地利用転換のパターンと似た土地利用転換 のシナリオとすることが出来る. 例えば「農地」への土地利用

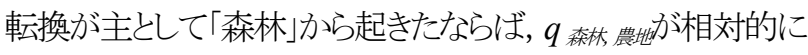
大きい. また， $q$ 森林農地の值を小さくし， $q$ そo他農地を大きくする ことで「森林」からではなく「その他」の土地を優先的に農地へ 転換するシナ师とすることが出来る.

GHG モジュールでは以上で得られた作付面積, 家畜頭数, 土地利用転換等に $\mathrm{GHG}$ 排出係数を乗じて $\mathrm{GHG}$ 排出量を 得る. GHG排出量の推計はIPCCによるインベントリガイドライ ン ${ }^{8)}$ 整合的である.これは各国が同ガイドラインに従って排 出量を推計していることを考慮し, データ入手や結果の比較 を容易にするためである. また土地利用からの排出量につい ては, 炭素ストックの差により求めている. 土地利用転換から 発生する $\mathrm{GHG}$ 排出量の排出係数は炭素ストック量の差によ り求める.

上記のように各モジュールを繋ぐことによって, 例えば, 食 糧需要の増加や食料の輸出入パターンの変化が対象地域 の $\mathrm{GHG}$ 排出量に与える影響を推計することや, エネルギー 部門の低炭素対策としてのバイオ燃料の需要が森林の農地 への転換を引き起こし土地利用部門からの GHG排出量の増 加を招く, といった関係を, AFOLU 部門全体の枠組みの中 で定量的に検討することが出来る.

本研究では, ExSS で将来のバイオマス需要量を計算し, AFOLUA モデルの外生変数しして入力し, AFOLU 部門での 土地利用転換がどのように変化するかが確認できるように改 良した。

\section{3. データとシナリオ想定}

\section{(1)対象地域の動向}

インドネシアの 2005 年時点での人口は 2 億 2448 万人であ ったが, 2020 年には 2 億 6941 万人, 2050 年には 3 億 2138 万 人になると予想されている 9. また, GDP 成長率は 2005 年か ら 2010 年の間で 5.7\%/年である. 2013 年の GDP 成長率は $5.7 \%$ /年と予想されており 12), 後も同程度以上の急な経済成 長が予想されており, 人為起源の $\mathrm{GHG}$ 排出量は今後も伸び ていくと予想される. GHG 排出においては, 農林業及びその 他の土地利用(Agriculture, Forestry and Other Land Use; AFOLU) 部門からの排出が過半を占めることが知られている. インドネ 
シア政府が国連気候変動枠組条約事務局へ提出した Second National Communication によれば 13), 2005 年の同国の GHG 排出量合計は $1,791 \mathrm{MtCO}_{2} \mathrm{eq}$ (二酸化炭素換算百万卜ン) でその内訳はエネルギー21\%, 産業プロセス 3\%, 農業 4\%, 土地利用 $38 \%$, 泥炭火災 $25 \%$, 廃棄物 9\%である. 2006年に 本格的なバイオエタノール, バイオディーゼルの生産を始め, インドネシア政府はエネルギー政策やバイオ然料について 法律によって定められた政策を発表している. それらの中で 大規模なプランテーション開発計画が書かれている ${ }^{14}$. また, 2013 年にはイイドネア政府からエネルギー・鉱物資源省規

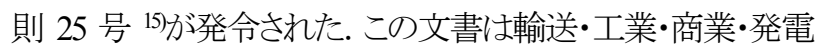
の各分野でバイオディーゼル利用の促進を図るものとなって いる.

\section{(2)シナリオの枠組み}

シナリオの枠組みを表-1 に示す. BaUシナ少才では低炭素 対策を特に施さず, 現在予測されている経済発展を続け, エ ネルギー, 農業, 土地利用の GHG 排出に関する諸要素は 基本的にこれまで通りを維持するシナ少才である. CM1 シナリ オはイバネシア政府の現行の低炭素政策に基づくシナ少才 である.ここでは $\mathrm{BaU}$ と同じ経済発展を前提しして低炭素対 策を導入し, 同国の目標である 2020 年にベースラインここで は BaUシナ少才)から 26\%削減を達成する. CM2, CM3シナリ
オはバイオ然料利用によるエネルギー部門の排出削減と土 地利用転換力らの排出の関係を CM1 との比較によって検討 するためのシナリオである. CM2 シナリオでは CM1シナリオ の低炭素対策に加えて自動車にバイオ燃料を導入し, バイ 才燃料の原材料はパームオイルとする.このとき参照土地利 用転換係数は $\mathrm{BaU}$ と同じものを用いる. CM3 シナ少才では $\mathrm{CM} 2$ から参照土地利用転換係数だけを変更し, 森林力ら農 地一の転換を抑制し，「その他」の土地から主に転換されるよ うにする. 表-2にシナ归の一覧を示した. その他に本研究で 対象とした AFOLU 部門の排出源及び対象となる排出ガスを 表-3 に示す.また, ExSS で対象とする産業部門を表-4 に 示L, AFOLUA で対象とする財を表-5に示す.

\section{（3）基準年デ一タについて}

エネルギー消費部門の基準年情報として, 人口, 産業連 関表, 旅客輸送量, 貨物輸送量などを国際連合(2012)9)など から収集して用いた. AFOLU 部門の基準年情報として, 農 林畜産業及びデータの大部分は, 国際連合食糧農業機関 (Food and Agriculture Organization of the United Nations ; FAO)の データベース(FAOSTAT) ${ }^{10)}$ からダウンロードしたものを用いた. FAOデータベースから得た基準年のデータを表-6に示す.
表-1シナリオの枠組み

\begin{tabular}{|c|c|}
\hline 項目 & 内容 \\
\hline 地域 & インドネシア \\
\hline 基準年 & 2005年 \\
\hline 目標年 & 2020年, 2050年 \\
\hline シナリオ名 & $\begin{array}{l}\text { 2020BaU, 2020CM1, } \\
\text { 2020CM2, 2020CM3, } \\
\text { 2050BaU, 2050CM1, } \\
\text { 2050CM2, 2050CM3 }\end{array}$ \\
\hline GHG & $\begin{array}{l}\text { 産業・交通・民生のエネルギー } \\
\text { 能費部門由来の } \mathrm{CO}_{2} \text {,農林業 } \\
\text { 及び土地利用転換由来の } \\
\mathrm{CO}_{2}, \mathrm{CH}_{4}, \mathrm{~N}_{2} \mathrm{O}\end{array}$ \\
\hline
\end{tabular}

表-3 AFOLU 部門の排出源及び $\mathrm{GHG}$

\begin{tabular}{lll}
\hline \multicolumn{1}{c}{ 排出源 } & \multicolumn{1}{c}{ 排出源小分類 } & 排出ガス \\
\hline 水田 & 窒素肥料 & $\mathrm{N}_{2} \mathrm{O}$ \\
& 稲作による排出 & $\mathrm{CH}_{4}$ \\
農作物 & 窒素肥料 & $\mathrm{N}_{2} \mathrm{O}$ \\
反忽家畜 & 家畜腸内発酵 & $\mathrm{CH}_{4}$ \\
家畜ふん尿 & ふん尿管理 & $\mathrm{CH}_{4}, \mathrm{~N}_{2} \mathrm{O}$ \\
泥炭地 & 泥炭酸化(農耕地) & $\mathrm{CO}_{2}$ \\
& 泥炭火岑 & $\mathrm{CO}_{2}$ \\
土地利用変化 & 土地利用変化 & $\mathrm{CO}_{2}$ \\
\hline
\end{tabular}

その他の文献から得たデータを表-7 に示す. FAO データ ベースでは農地以外の土地利用データが収録されていない

\begin{tabular}{|c|c|c|}
\hline & 2020 & 2050 \\
\hline $\mathrm{BaU}$ & •対策なし & •対策なし \\
\hline CM1 & $\begin{array}{l}\text { •両部門でGHG排出量 } \\
26 \% \text { 削減 }\end{array}$ & $\begin{array}{l}\text { •2020年のシナリオを延 } \\
\text { 長 } \\
\text { •発電用燃料の多様化 }\end{array}$ \\
\hline $\mathrm{CM} 2$ & $\begin{array}{l}\text { •CM1の想定に加え、交 } \\
\text { 通部門の石油燃料の } \\
\text { 10\%をバイオ然料に }\end{array}$ & $\begin{array}{l}\text { •CM1の想定に加え、交 } \\
\text { 通部門の石油燃料の } \\
25 \% \text { ゙ハイオオ然料に }\end{array}$ \\
\hline CM3 & $\begin{array}{l}\text { •CM2の想定に加え、 } \\
\lceil そ の \text { 他」の土地を優先 } \\
\text { 的に農地に転換 }\end{array}$ & $\begin{array}{l}\text { •CM2の想定に加え、 } \\
\lceil そ の \text { 他」の土地を優先 } \\
\text { 的に農地に転換 }\end{array}$ \\
\hline
\end{tabular}

\begin{tabular}{cl}
\multicolumn{2}{c}{ 表-4 ExSS で対象とする産業部門 } \\
\hline 分類 & \multicolumn{1}{c}{ 部門 } \\
\hline 第一産業 & 農林水産業 \\
第二次産業 & 鉱工業, 食品加工, \\
& 㵶維・パルプ, 化 \\
& 学, 建設, 鉄鋼, セ \\
& メント, その他製造 \\
& 業 \\
第三次産業 & サービス業 \\
\hline
\end{tabular}

ため, USGS のリモートセンシングによる 2001 年及び 2006 年 のおけるイントネシア全土の土地利用によって補完し, これら 
2 時点間の土地利用を比較して 2001 年から 2006 年にかけて の土地利用転換行列を作成した.この土地利用転換行列を 表-9 に示す.これから求めた土地利用転換係数を $\mathrm{BaU}$ シナ リオにおける参照土地利用転換係数しして用いた. 土地利用 転換からの排出係数を求めるための土地利用用途別の炭素 ストック量を表-8に示した.

\section{(4)将来の社会経済指標}

人口, 社会経済指標についてはシナリオの種類によらず,

\begin{tabular}{|c|c|}
\hline 分類 & 品目 \\
\hline 農作物 & $\begin{array}{l}\text { 米, 小麦, その他穀物, 野菜類, 果実類, キャッサバ, サトウキ } \\
\text { ビ, 砂糖, 植物油, パーム油(食用・燃料用), 油糧作物, パーム, } \\
\text { その他食料作物, 工芸作物, ジャトファア }\end{array}$ \\
\hline 畜産物 & $\begin{array}{l}\text { 食肉(牛, 豚, 羊, ヤギ, バッファロー, 馬, 鵎, アヒ } \\
\text { ル), 生乳(牛, 羊, ヤギ), 卵(鷄, その他), 乳製品 }\end{array}$ \\
\hline 水産物 & 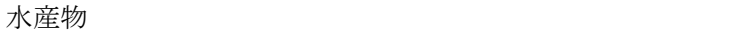 \\
\hline 林産物 & $\begin{array}{l}\text { 産業用丸太, 燃料用丸太, 伐採残椬, 繊維板, 製材, パルプ, } \\
\text { その他工業木材 }\end{array}$ \\
\hline 残差 & $\begin{array}{l}\text { 作物残椬, バルボジョ, バガス, パーム残椬(空房, パルプ, 工場 } \\
\text { 排水), 家音霬尿, 製材残渣, 食物残渣 }\end{array}$ \\
\hline
\end{tabular}

表-7 その他文献から得た基準年データ

\begin{tabular}{|c|c|}
\hline 項目 & 参考文献 \\
\hline 土地利用用途別炭 & Shrestha et al. ${ }^{22)}$, 電力中央研究所 ${ }^{25}$,Germer et \\
\hline 素ストック量 & $\mathrm{aP}^{26}$, IFEU $^{27}$, Gnanavelrajah et al. ${ }^{28}$, Wicke et al. ${ }^{23}$ \\
\hline $\begin{array}{l}\text { エネルギ一作物の燃 } \\
\text { 料転換率 }\end{array}$ & 電力中央研究所 ${ }^{25)}$ \\
\hline $\begin{array}{l}\text { 残椬系バイオマス発 } \\
\text { 生係数, 高位発熱量 }\end{array}$ & Wicke etal. ${ }^{23)}$, 日本エネルギー学会 ${ }^{24)}$ \\
\hline
\end{tabular}

同じ目標年では同じ推計值を使う. 人口・一世帯当たり人員 世帯数・世帯数を表-10 に示す.アジア開発銀行(Asia Development Bank, ADB) ${ }^{12)}$ は 2014 年の GDP 成長率を 6.0\% 推計したため, 2005 年から 2020 年まではこの值を用いること とした. 2021 年から 2050 年までの GDP 成長率は $\mathrm{ADB}^{17) や ~}$

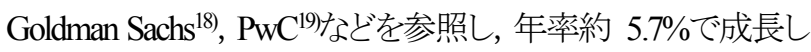
続けるとした. 産業構造はインドネシア国営電力公社 20 による 過去の産業別生産額の構成比を延長するものとした。

\begin{tabular}{ll} 
表-6 FAOデータベースから得た基準年情報 \\
\hline \multicolumn{1}{c}{ 項目 } & \multicolumn{1}{c}{ 区分 } \\
\hline 食糧需要量 & 品目 \\
食糧生産量 & 品目 \\
食糧輸出入量 & 品目 \\
家畜頭羽数 & 品種 \\
家畜用土地面積 & 品種 \\
単収, 収量 & 品目 \\
農地面積 & 用途 \\
収穫面積 & 品目 \\
排出係数 & 排出源 \\
\hline
\end{tabular}

表-8 土地利用用途別炭素ストック

\begin{tabular}{lrc}
\hline \multicolumn{1}{c}{ 土地形態 } & $\begin{array}{c}\text { 炭素ストック } \\
\text { 量(tCha) }\end{array}$ & 参照 \\
\hline 熱帯雨林 & 233.6 & $23)$ \\
パーム栽培地 & 93.1 & $23)$ \\
荒地 & 62.5 & $23)$ \\
水田 & 71.0 & $28)$ \\
果樹園 & 184.7 & $28)$ \\
工芸作物栽培(生ゴムなど) & 240.0 & $28)$ \\
牧草地 & 11.5 & $28)$ \\
その他作物栽培 & 27.0 & $22)$ \\
\hline
\end{tabular}

表-9 2001年から 2006年の土地利用転換行列

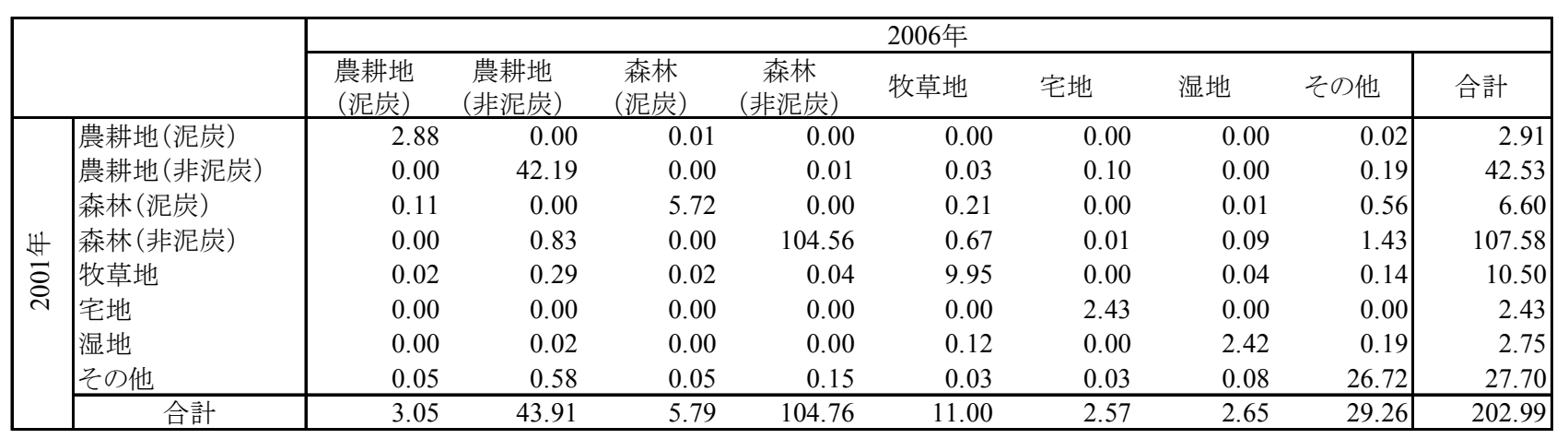

表-10 人口・一世帯当たり人員世帯数・世帯数

\begin{tabular}{llrrrrr}
\hline & 単位 & \multicolumn{1}{c}{2005} & \multicolumn{1}{c}{2020} & \multicolumn{1}{c}{2050} & $2020 / 2005$ & $2050 / 2005$ \\
\hline 人口 & 千人 & 224,481 & 269,413 & 321,377 & 1.20 & 1.43 \\
一世帯当たり人員 & 人 $/$ 世帯 & 3.86 & 3.42 & 2.69 & 0.89 & 0.70 \\
世帯数 & 世帯 & 58,152 & 78,819 & 119,596 & 1.36 & 2.06 \\
\hline
\end{tabular}


表-11 産業別生産額の構成比

\begin{tabular}{|c|c|c|c|c|c|}
\hline & 2005 & 2020 & 2050 & $\begin{array}{l}2020 \\
/ 2005\end{array}$ & $\begin{array}{l}2050 \\
/ 2005\end{array}$ \\
\hline 農林水産業 & $9.3 \%$ & $7.5 \%$ & $9 \%$ & 0.8 & 0.9 \\
\hline 鉱業·採石業 & $6.8 \%$ & $4.4 \%$ & $3.6 \%$ & 0.6 & 0.5 \\
\hline 食料品産業 & $9.0 \%$ & $11.0 \%$ & $13.1 \%$ & 1.2 & 1.5 \\
\hline 繊維産業 & $7.2 \%$ & $3.7 \%$ & $2.9 \%$ & 0.5 & 0.4 \\
\hline 化学産業 & $9.6 \%$ & $4.7 \%$ & $3.3 \%$ & 0.5 & 0.3 \\
\hline 建設業 & $10.2 \%$ & $7.8 \%$ & $7.6 \%$ & 0.8 & 0.7 \\
\hline その他の産業 & $4.7 \%$ & $14.6 \%$ & $16 \%$ & 3.1 & 3.3 \\
\hline 鉄鋼業 & $7.5 \%$ & $2.4 \%$ & $1.6 \%$ & 0.3 & 0.2 \\
\hline 窯業 & $0.4 \%$ & $0.6 \%$ & $0.6 \%$ & 1.6 & 1.5 \\
\hline サービス業 & $35 \%$ & $43 \%$ & $43 \%$ & 1.2 & 1.2 \\
\hline 合計 & $100 \%$ & $100 \%$ & $100 \%$ & 1.0 & 1.0 \\
\hline
\end{tabular}

表-13 2020年·2050年の貨物輸送機関分担率

\begin{tabular}{llrrrr}
\hline & & 自動車 & 鉄道 & \multicolumn{1}{c}{ 船舶 } & 飛行機 \\
\hline \multirow{2}{*}{2005} & 国内 & $95.8 \%$ & $1.8 \%$ & $2.4 \%$ & $0.1 \%$ \\
& 国外 & $0.0 \%$ & $0.0 \%$ & $98.1 \%$ & $1.9 \%$ \\
$\mathrm{BaU}$ & 国内 & $95.8 \%$ & $1.8 \%$ & $2.4 \%$ & $0.1 \%$ \\
$\mathrm{CM} 1, \mathrm{CM} 2$, & 国内 & $0.0 \%$ & $0.0 \%$ & $98.1 \%$ & $1.9 \%$ \\
$\mathrm{CM} 3$ & 国外 & $0.0 \%$ & $1.8 \%$ & $2.4 \%$ & $0.1 \%$ \\
\hline
\end{tabular}

\section{(5) 2020年のシナリオ想定}

2020 年においては, 2020BaU, 2020CM1, 2020CM2, $2020 \mathrm{CM} 3$ の 4 つのシナ少才を構築した. ここで BaU(business as usual)之は GHG排出量削減を一切行わない場合を示L, エ ネルギー部門についてはエネルギー効率およびエネルギー 最終需要部門でのエネルギー構成比を基準年の值で固定, 発電においては現在のインドネシア政府の政策に従い石炭 火力の割合を 2005 年の $40 \%$ から 60\%に増加した. AFOLU 部 門では排出係数を 2005 年から一定ししたほか, 2001 年から 2006 年の土地利用転換係数を将来に渡っても参照土地利 用転換係数しして利用した. エネルギー部門の CM ケースの 対策, 特に CM1 シナ少オではイイドネシア政府が 2010 年に 策定した目標である26\%削減を達成するように設定した(コペ ンハーゲン合意に基づき, 2010 年 1 月に気候変動枠組条約 (UNFCCC)に削減行動として提出済み). CM2 では更に石 油然料の一部にバイオエタノールな゙といったバイオ燃料を 導入することとした. また AFOLU 部門において, 森林からの 土地利用転換の抑制, 泥炭火災の抑制, 泥炭酸化の抑制, 家畜から排出される $\mathrm{GHG}$ の抑制を行っている. CM3 では $\mathrm{CM} 2$ に加え, バイ才然料を生産するプランテーションの場所 を主に森林ではなく,「その他」土土地利用用途から転換させ
表-12 2020年の旅客輸送機関分担率

\begin{tabular}{lcrrrr}
\hline & & 自動車 & \multicolumn{1}{c}{ バス } & 鉄道 & 二輪車 \\
\hline 2005 & 国内 & $19.3 \%$ & $11.5 \%$ & $0.7 \%$ & $24.6 \%$ \\
& 国外 & $0.0 \%$ & $0.0 \%$ & $0.0 \%$ & $0.0 \%$ \\
$2020 \mathrm{BaU}$ & 国内 & $29.0 \%$ & $15.0 \%$ & $2.0 \%$ & $30.0 \%$ \\
& 国外 & $0.0 \%$ & $0.0 \%$ & $0.0 \%$ & $0.0 \%$ \\
$2020 \mathrm{CM} 1$, & 国内 & $13.6 \%$ & $19.3 \%$ & $28.3 \%$ & $14.6 \%$ \\
$\mathrm{CM} 2, \mathrm{CM} 3$ & 国外 & $0.0 \%$ & $0.0 \%$ & $0.0 \%$ & $0.0 \%$ \\
\hline \multirow{2}{*}{2005} & & 船舶 & 飛行機 & 徒歩 & 自転車 \\
\hline \multirow{2}{*}{$2020 \mathrm{BaU}$} & 国内 & $5.0 \%$ & $2.7 \%$ & $29.0 \%$ & $7.2 \%$ \\
& 国外 & $10.0 \%$ & $90.0 \%$ & $0.0 \%$ & $0.0 \%$ \\
$2020 \mathrm{CM} 1$, & 国内 & $4.0 \%$ & $5.0 \%$ & $5.0 \%$ & $10.0 \%$ \\
$\mathrm{CM} 2, \mathrm{CM} 3$ & 国外 & $10.0 \%$ & $90.0 \%$ & $0.0 \%$ & $0.0 \%$ \\
& 国内 & $4.0 \%$ & $5.0 \%$ & $5.1 \%$ & $10.1 \%$ \\
\hline
\end{tabular}

表-14 2050年旅客輸送機関分担率

\begin{tabular}{llrrrr}
\hline & & 自動車 & \multicolumn{1}{c}{ バス } & 電車 & 二輪車 \\
\hline 2005 & 国内 & $19.3 \%$ & $11.5 \%$ & $0.7 \%$ & $24.6 \%$ \\
& 国外 & $0.0 \%$ & $0.0 \%$ & $0.0 \%$ & $0.0 \%$ \\
$2050 \mathrm{BaU}$ & 国内 & $24.6 \%$ & $32.8 \%$ & $20.5 \%$ & $12.3 \%$ \\
& 国外 & $0.0 \%$ & $0.0 \%$ & $0.0 \%$ & $0.0 \%$ \\
$2050 \mathrm{CM} 1$, & 国内 & $11.1 \%$ & $17.6 \%$ & $36.0 \%$ & $13.3 \%$ \\
$\mathrm{CM} 2, \mathrm{CM} 3$ & 国外 & $0.0 \%$ & $0.0 \%$ & $0.0 \%$ & $0.0 \%$ \\
\hline \multirow{2}{*}{2005} & & 船舶 & 飛行機 & 徒歩 & 自転車 \\
\hline \multirow{2}{*}{$2050 \mathrm{BaU}$} & 国内 & $5.0 \%$ & $2.7 \%$ & $29.0 \%$ & $7.2 \%$ \\
& 国外 & $10.0 \%$ & $90.0 \%$ & $0.0 \%$ & $0.0 \%$ \\
$2050 \mathrm{CM} 1$, & 国内 & $1.6 \%$ & $1.6 \%$ & $4.1 \%$ & $2.5 \%$ \\
$\mathrm{CM} 2, \mathrm{CM} 3$ & 国外 & $10.0 \%$ & $90.0 \%$ & $0.0 \%$ & $0.0 \%$ \\
\hline
\end{tabular}

て生産させるシナリオとした. エネルギー消費部門における 旅客輸送, 貨物輸送の想定を表-12, 表-13 に示した. AFOLU 部門では一人当たり食糧需要, 輸出, 単収を過去 10 年の傾 向を延長して与え, 輸入率は 2005 年の值で固定した.

\section{(6) 2050年のシナリオ想定}

2050 年では人口が 3 億 2138 万人となり, GDPも 2005 年比 で約 19 倍となる. そのため, 多くの温室効果ガスが排出され ると予測出来る. 2050 年においてもシナ少才は 4 つ(2050BaU, 2050CM1, 2050CM2, 2050CM3)ある. 2020 年の想定と同様に $\mathrm{BaU}$ シナリオをまず計算する. 自動車の割合は依然 2005 年

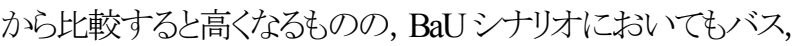
電車といった公共交通機関での移動が主流となると想定した. また，二輪車の機関分担率は減少する. 2050 年における旅 客輸送の想定を表-14 に示した. 貨物輸送については 2020 年と同じ想定をしている. CM1 シナ少オでは2020年のCM1シ ナ少オ 2050 年まで継続した場合のシナ少オとなっている. CM2では2020年同様バイオ然料を導入するが, 2050年の推 計ではバイオ燃料を $25 \%$ 導入することとした. CM2 シナ少才も 2020 年の CM2 シナ少才を延長して推計した. AFOLU 部門の 推計についてもそれぞれのシナ归オの延長とした. 


\section{4. 結果と考察}

\section{(1)最終エネルギ一需要量}

部門別最終エネルギ一需要量の推計結果を表-15 に示寸. 最終エネルギー需要量の合計は, 2020 年 $\mathrm{BaU}$ シナリオでは 2005 年比で 2.63 倍, CMシナ少オでは 2005 年比で 2.11〜2.33 倍となった. また 2050 年 $\mathrm{BaU}$ シナリオでは 2005 年比で 10.7 倍, CMシナリオでは 2005 年比で約 9.0 倍となった.

\section{(2) GHG排出量}

GHG 排出量の推計結果を表-16, 図-3, 図-4 に示寸. 2020
年の $\mathrm{BaU}$ シナリオに対し, $\mathrm{CM} 1$ シナ师 $\mathrm{CM} 2$ シナリオ, $\mathrm{CM} 3$ シナ少オの削減割合はそれぞれ $26 \%, 24 \%, 30 \%$ となった.こ の内, インドネシアの公式の目標である 26\%削減目標に届い たシナ少オは CM1 シナ沙と CM3 シナリオであり, CM2 シナ リオでは達成出来なかった. 2005年から 2050年までの推計を 比較すると, エネルギー部門と AFOLU 部門の排出量の割合 が変化している. エネルギー消費部門からの GHG 排出量は 人口と GDP に比例して伸びる傾向にある. それに対して AFOLU 部門の排出量は GDP に比例的に成長するとは考え られない. そのため 2005 年には全体の $11 \%$ ん占めていな かったエネルギー起源排出量が 2050 年では75\%となった。

表-15 最終エネルギ一需要量(Mtoe)

\begin{tabular}{|c|c|c|c|c|c|c|c|c|}
\hline & & 石炭 & 石油 & 天然ガス & バイオマス & 電力 & バイ才然料 & 合計 \\
\hline \multirow[t]{2}{*}{2005} & & 10 & 45 & 10 & 40 & 10 & 0 & 115 \\
\hline & $\mathrm{BaU}$ & 52 & 94 & 32 & 56 & 39 & 0 & 274 \\
\hline \multirow[t]{3}{*}{2020} & CM1 & 51 & 82 & 33 & 53 & 39 & 0 & 258 \\
\hline & $\mathrm{CM} 2, \mathrm{CM} 3$ & 42 & 70 & 32 & 53 & 39 & 17 & 237 \\
\hline & $\mathrm{BaU}$ & 104 & 387 & 177 & 198 & 188 & 0 & 1052 \\
\hline \multirow[t]{2}{*}{2050} & CM1 & 101 & 341 & 173 & 195 & 210 & 0 & 1019 \\
\hline & $\mathrm{CM} 2, \mathrm{CM} 3$ & 101 & 258 & 173 & 195 & 210 & 83 & 1020 \\
\hline
\end{tabular}

表-16 GHG 排出量 $\left(\mathrm{MtCO}_{2} \mathrm{eq}\right)$

\begin{tabular}{|c|c|c|c|c|c|c|}
\hline & & \multirow[t]{2}{*}{2005} & \multicolumn{4}{|c|}{2020} \\
\hline & & & $\mathrm{BaU}$ & CM1 & $\mathrm{CM} 2$ & CM3 \\
\hline エネルギー & 家庭部門 & 69 & 176 & 168 & 168 & 168 \\
\hline \multirow[t]{5}{*}{ 消費部門 } & 業務部門 & 28 & 182 & 177 & 173 & 173 \\
\hline & 産業部門 & 134 & 506 & 491 & 433 & 433 \\
\hline & 旅客輸送部門 & 51 & 88 & 63 & 57 & 57 \\
\hline & 貨物輸送部門 & 29 & 61 & 61 & 55 & 55 \\
\hline & 合計 & 311 & 1,013 & 960 & 887 & 887 \\
\hline \multirow[t]{6}{*}{ AFOLU部門 } & 農林業由来 & 58 & 73 & 63 & 63 & 63 \\
\hline & 家畜由来 & 24 & 36 & 30 & 30 & 30 \\
\hline & 土地利用変化 & 706 & 753 & 397 & 494 & 331 \\
\hline & 泥炭火災 & 451 & 294 & 225 & 202 & 225 \\
\hline & 泥炭酸化 & 379 & 571 & 331 & 372 & 372 \\
\hline & 合計 & 1,618 & 1,726 & 1,046 & 1,161 & 1,020 \\
\hline \multicolumn{2}{|c|}{ GHG排出量 $\left(\mathrm{MtCO}_{2} \mathrm{eq}\right)$} & 1,929 & 2,739 & 2,006 & 2,047 & 1,907 \\
\hline & & & \multicolumn{4}{|c|}{2050} \\
\hline & & & $\mathrm{BaU}$ & CM1 & CM2 & CM3 \\
\hline エネルギー & 家庭部門 & & 217 & 153 & 131 & 131 \\
\hline \multirow[t]{5}{*}{ 消費部門 } & 業務部門 & & 833 & 545 & 498 & 498 \\
\hline & 産業部門 & & 2,101 & 1,493 & 1,355 & 1,355 \\
\hline & 旅客輸送部門 & & 79 & 53 & 43 & 43 \\
\hline & 貨物輸送部門 & & 303 & 253 & 206 & 206 \\
\hline & 合計 & & 3,534 & 2,497 & 2,233 & 2,233 \\
\hline \multirow[t]{7}{*}{$\begin{array}{l}\text { AFOLU部門 } \\
\end{array}$} & 農林業由来 & & 86 & 64 & 64 & 64 \\
\hline & 家畜由来 & & 48 & 40 & 40 & 40 \\
\hline & 土地利用変化 & & 448 & 217 & 453 & 313 \\
\hline & 泥炭火災 & & 170 & 201 & 126 & 191 \\
\hline & 泥炭酸化 & & 996 & 331 & 386 & 386 \\
\hline & 合計 & & 1,748 & 853 & 1,069 & 994 \\
\hline & & & 5,283 & 3,350 & 3,303 & 3,227 \\
\hline
\end{tabular}




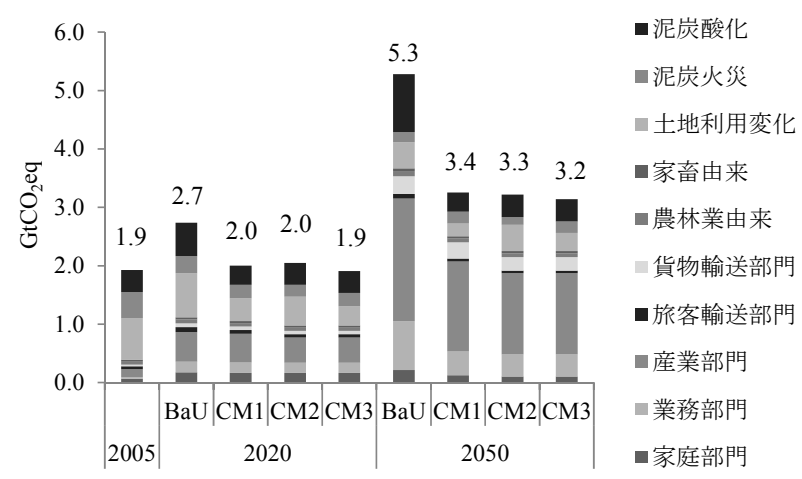

図-3 GHG排出量

\section{(3) 考察}

$\mathrm{CM} 2$ シナ师オでは CM1 シナ师オよりも $\mathrm{GHG}$ 排出量が多く なり, インドネア政府の 2020 年の目標は達成できなかった. これは, バイオ燃料を使用寸るために AFOLU 部門でのその 原料となるオイルパームの生産量が伸び, バイオ燃料をもち いることによる GHG 削減と, 森林を伐採して農地に転換した ことによる GHG 排出とが正味で排出になったためである.

これに対して CM3 シナリオでは森林ではなく,「その他」と して分類されている土地を農地に積極的に転換するよう想定 した結果, GHG 排出量は CM1 に比較して約 5\%低く, 正味 で削減となった. また $\mathrm{BaU}$ からの $\mathrm{GHG}$ 排出量削減のうち約 12\%を占めることとなった.

\section{5. まとめ}

本研究ではエネルギー, 農業, 土地利用の相互の影響を 総合的な低炭素社会シナリオの枠組みの中で考慮すること が出来る手法を開発した. このような考慮はインドネシアのよ うな AFOLU 部門からの排出の割合が比較的高く, またバイ 才燃料の生産が低炭素対策しして考慮されるような国・地域 において低炭素社会を構築しようとする際に有用であると考 える. 今後の課題として, ここでのインドネシアにおける適用 例は基準年が 2005 年と現在までに時間が経っていることや， 限られたデー夕に基づいていることから, 社会経済発展の見 込み, バイオ燃料の生産諸元, インドネシアにおける農業か らの詳細な排出係数, 土地利用種別の炭素ストックなどのよ り正確·詳細なデータが入手されたならば更新されるべきで あることが挙げられる. また, この手法を活用し, 自動車用燃 料用以外も含むバイオ燃料生産が正味の GHG 排出削減と なるような諸条件(原材料作物の選択, 農地に転換する土地, 生産効率, バイオ燃料が利用されない場合の燃料等)の範囲 や, エネルギーや廃棄物部門の対策も含めて国全体の排出 削減策の中での相対的重要性等について詳細な検討をす るためのシナ归開発が必要と思われる.

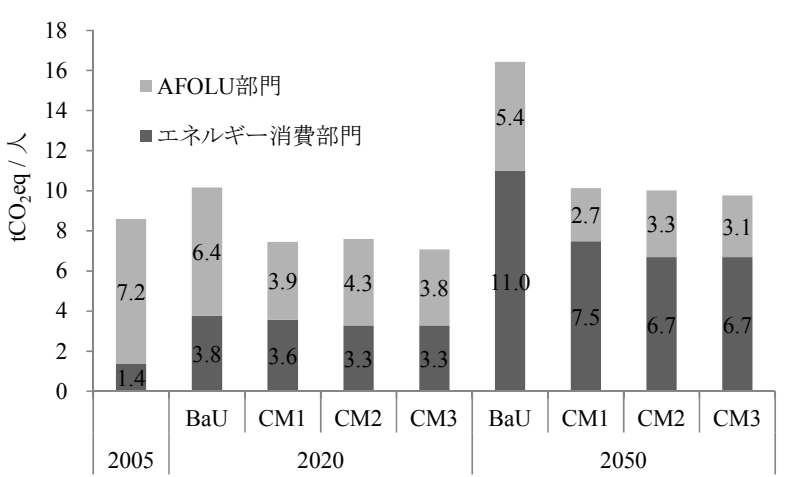

図-4 一人当たり GHG 排出量

謝辞: 本研究は, 環境省の地球環境研究総合推進費(S-62), 科学技術振興機構: 地球規模課題対灾国際科学技術協 力事業(SATREPS)の支援により実施された. またインドネシア の土地利用データについてボゴール農科大学のRizaldi Boer 教授の協力を受けた. ここに記して感謝の意を表する.

\section{参考文献}

1) International Monetary Fund: World Economic Outlook, 2013.

2) World Resource Institute, CAIT2.0: http://cait2.wri.org/

3) National Council for Climate Change (DNPI): Indonesia's Greenhouse Gas Abatement Cost Curve, 2010.

4) International: Peatland degradation fuels climate change, 2006.

5) UNEP: Towards sustainable production and use of resources Assessing Biofuel, 2009.

6) 五味馨: 仲座方伯,松岡譲, 地域経済の開放性を考慮した低炭素 社会シナリオ構築手法の開発と京都市への適用, 環境システム 研究論文集, 36,pp1-10,2008.

7) 三隅卓矢: 農林業及び土地利用転換を考慮した低炭素社会シ ナ少才構築手法の開発, 京都大学修士論文, 2013.

8) IPCC: IPCC Guidelines for National Greenhouse Gas inventories, 2006.

9) United Nations: World Population Prospects: The 2012 Revision, 2012. 10)FAOSTAT: http://faostat.fao.org/

11)USGS: http://glovis.usgs.gov/

12) ADB: http://www.adb.org/countries/indonesia/ economy

13) Ministry of Environment, Republic of Indonesia: Indonesia Second National Communication UNDER The United Nations Framework Convent ion on Climate Change, 2010.

14) Center for Intemational Forestry Research: Policy and institutional frameworks for the development of palm oil-based biodiesel in Indonesia, 2011.

15) Ministry of Energy and Mineral Resources: Republic Indonesia, EMR Regulation No.25, 2013.

16) Hooijer, A., Silvius, M., Wösten, H., and Page, S.: Assesment of $\mathrm{CO} 2$ emissions from drained peatlands in SE Asia, 2006.

17) Asia Development Bank: ASIA 2050, 2011.

18) Goldman Sachs: The N-11: More Than an Acronym, 2007. 
19) PricewaterhouseCoopers: World in 2050, 2013.

20)イイドネア国営電力公社: PLN STATISTICS 2012,2012.

21)イイドネシア統計局: Statistics Indonesia, http://www.bps.go.id/

22) Shretha, P., Vogt, D., Gnanavelrajah, N.: Relating plant diversity to biomass and soil erosion in a cultivated landscape of the eastem seaboard region of Thailand, Applied Geography, 30, pp606-617, 2010.

23) Wicke, B., Domburg, V., Iunginger, M., Faaij, A.: Different palm oil production systems for energy purposes and their greenhouse gas implications, Biomass and Bioenergy, 32, pp1322-1337, 2008.

24) 日本エネルギー学会:バイオマスハンドブック,2002.

25) 電力中央研究所: バイオ燃料としてのジャトロファ油のポテンシャ ル評価, 2009 .
26) Germer, J., Sauerbom, J: Estimation of the impact of oil palm plantation establishment on greenhouse gas balance. Environment, Development and Sustainability, 10, pp697-716, 2008.

27) IFEU: Base data for Jatropha production and use - updated version - , 2008.

28) Gnanavelrajah R., Shrestha, P., Vogt, D. Samarakoon, L.: Carbon Stock Assessment and Soil Carbon Management in Agricultural Land-Uses in Thailand, Land Degrad. Develop. 19, pp242-256, 2008.

29) Hooijer, A., Silvius, M., Wösten, H., Page, S.: Assessment of $\mathrm{CO}_{2}$ emissions from drained peatlands in SE Asia, 2006.

30) Ministry of Environment, Republic of Indonesia: Indonesia First National Communication, 1994.

(2014. 3. 28 受付)

\section{DEVELOPMENT OF LOW CARBON SOCIETY SCENARIOS CONSIDERING ENERGY AND AGRICULTURE, FORESTRY AND LANDUSE IN INDONESIA}

\section{Ryohei OSAWA, Kei GOMI and Yuzuru MATSUOKA}

Among Southeast Asian countries in which population and economic growth is expected, Indonesia is considered especially important in terms of mitigation of global warming because of its population size, wide forestland, and high agriculture production. For such a country where population and economy are growing, increase of food and energy demand is expected, and GHG emission from AFOLU (Agriculture, Forestry and Other Land use) sector has a significant share, we propose an integrated approach for lowcarbon society scenario. The methodology was applied in Indonesia and one BaU (business as usual) scenario and three CM (countermeasure) scenarios were developed, and showed an example to consider net effect of biofuel. 